\title{
The circulation of Ghlin flint during the time of the Blicquy - Villeneuve-Saint-Germain culture (Early Neolithic)
}

\author{
Solène Denis \\ Université Paris Ouest Nanterre la Défense, CNRS-UMR 7055, Maison de l'Archéologie et de l'Ethnologie, \\ UMR 7055 Préhistoire et Technologie, 21, allée de l'Université, 92023 Nanterre cedex, France. \\ Email: denis.solene@gmail.com
}

\begin{abstract}
:
In the North of France and Belgium, the Blicquy - Villeneuve-Saint-Germain culture marks the end of the Early Neolithic Period (beginning of the $5^{\text {th }}$ millennium). The Blicquy group is constituted of eleven sites located in Belgium, with two main centers of occupation: one Western in Hainaut and one Eastern in Hesbaye, $100 \mathrm{~km}$ away from the first. As part of a $\mathrm{PhD}$, the lithic industry of these sites is studied in order to reconstruct the circulation networks through a techno-economic analysis. It has been complex to identify the raw materials, given the lack of information about the siliceous outcrops in the Mons Basin. However, two main circulation networks have been highlighted: one of Ghlin flint and one of tertiary Bartonian flint. These two types of flint are indeed easily recognizable by their macroscopic characteristics. The outcrops of tertiary Bartonian flints originate from the Paris Basin, where systematic surveys have been conducted since the late 1980s. The circulation of tertiary Bartonian flint is now well-known and emblematic of the Blicquy - Villeneuve-Saint-Germain culture. Therefore, this paper will focus on the circulation of Ghlin flint in the Blicquy-Villeneuve-SaintGermain culture. The Ghlin flint shows on the surface in the Mons Basin, about twenty kilometers away from the Hainaut sites. Heavily exploited in the latter, it was exported to the Hesbaye sites in a significant way, despite the availability of siliceous resources available in Hesbaye. Moreover, some artifacts circulated towards the Paris Basin. The study of the circulation of Ghlin flint can therefore help to determine the socio-economic organization of these populations by specifying the linkages between the population centers of Hainaut, Hesbaye and Paris Basin.
\end{abstract}

Keywords: Early Neolithic period; Blicquy - Villeneuve-Saint-Germain culture; circulation networks; Ghlin flint

\section{Résumé}

Dans le Nord de la France et en Belgique, la culture Blicquy - Villeneuve-Saint-Germain marque la fin du Néolithique ancien (début du $5^{\text {ème }}$ millénaire). Les onze sites découverts en Belgique constituent le faciès blicquien de cette culture. Deux aires d'occupation peuvent être distinguées. La première, localisée en Hainaut est distante d'une centaine de $\mathrm{km}$ de la seconde, située plus à l'est, en

Published by the School of History, Classics and Archaeology, University of Edinburgh ISSN: 2055-0472. URL: http://journals.ed.ac.uk/lithicstudies/

This work is licensed under a Creative Commons Attribution 2.5 UK: Scotland License. 
Hesbaye. L'industrie lithique des sites blicquiens est étudiée dans le cadre d'une thèse visant à reconstruire les réseaux de circulation des matières siliceuses par le biais d'une analyse technoéconomique. La lithothèque étant en construction dans le Bassin de Mons (Hainaut), les gîtes de matières premières restent encore mal connus malgré des potentialités importantes. Toutefois, deux réseaux de circulation ont pu être mis en évidence : celui du silex de Ghlin et celui du silex tertiaire bartonien. Ces deux silex sont aisément identifiables par leurs caractéristiques macroscopiques. Les gisements de silex tertiaire bartonien sont localisés dans le Bassin parisien qui a fait l'objet de prospections systématiques dès la fin des années 80 . La circulation du silex tertiaire bartonien est désormais bien connue et emblématique de la culture Blicquy - Villeneuve-Saint-Germain. Aussi, cet article s'intéressera prioritairement à la circulation du silex de Ghlin. Ce silex, bien que les gîtes ne soient pas précisément localisés, affleurerait dans le Bassin de Mons, soit à une vingtaine de $\mathrm{km}$ des sites hennuyers. Dominant dans ces assemblages, le silex de Ghlin a circulé de manière significative vers les sites de Hesbaye. Pourtant, les ressources siliceuses y sont nombreuses et de bonne qualité. De même, quelques pièces circulent vers le Bassin parisien. Ainsi, l'étude de la circulation du silex de Ghlin est un moyen pertinent pour comprendre les relations entretenues entre les populations du Hainaut, de Hesbaye et du Bassin parisien.

Mots-clefs: Néolithique ancien, culture Blicquy - Villeneuve-Saint-Germain, réseaux de circulation, silex de Ghlin

\section{Riassunto}

Nel nord della Francia e in Belgio, la cultura Blicquy - Villeneveuve-Saint Germain segna la fine del Neolitico antico (inizi del V millennio). Gli undici siti scoperti in Belgio rappresentano le facies "blichiane" di questa cultura. Si possono distinguere due aree insediative. La prima localizzata in Hainaut dista circa un centinaio di $\mathrm{km}$ dalla seconda ed è situata più ad est, in Hesbaye. L'industria litica dei siti di Bliquy è stata studiata nell'ambito di un lavoro di Tesi dottorale con l'obiettivo di ricostruire le risorse di circolazione delle materie prime silicee attraverso l'analisi tecno-economica. Nel Bacino di Mons (Hainaut), la litoteca è ancora in fase di realizzazione, non si conoscono bene $\mathrm{i}$ giacimenti di materia prima nonostante le loro importanti potenzialità. Tuttavia, si sono potute evidenziare due risorse di circolazione: quella della selce di Ghlin e quella della selce terziaria bartoniana. Questi due tipi di selce sono facilmente discriminabili attraverso i loro caratteri macroscopici. I giacimenti di selce terziaria bartoniana si localizzano nel Bacino parigino che è stato oggetto di sistemetiche prospezioni già dalla fine degli anni '80. La circolazione della selce terziaria bartoniana è ormai ben nota ed è emblematica della cultura di Bliquy - Villeneveuve-Saint Germain. Quest'articolo s' interesserà in modo prioritario alla circolazione della selce di Ghlin. Tale tipologia di selce, benché i giacimenti non siano localizzati in modo preciso, affiora nel Bacino di Mons e a una ventina di km dai siti hennuyers. Dominante in queste collezioni, la selce di Ghlin ha circolato in modo significativo verso i siti di Hesbaye. Pertanto, le risorse silicee sono numerose e di buona qualità. Allo stesso modo, qualche elemento circola verso il Bacino parigino. In questo senso, lo studio della circolazione della selce di Ghlin rappresenta una maniera pertinente per capire le relazioni che si sono intrattenute tra le popolazioni di Hainaut, di Hesbaye e del Bacino parigino.

Parole chiave: Neolitico antico, cultura Blicquy - Villeneveuve-Saint Germain, risorse di circolazione, selce di Ghlin

\section{General presentation}

\subsection{Geographical and chronological context}

In the North of France and Belgium, the Blicquy - Villeneuve-Saint-Germain (BQ-VSG) culture marks the end of the Early Neolithic Period (beginning of the $5^{\text {th }}$ millennium). The BQ-VSG culture extends in the North of France and in Belgium (Figure 1). The radiometric 
data situate the VSG group between 4950 to 4650 cal BC (Dubouloz 2003). According to the study of the ceramics, this culture was divided in 3 chronological stages (early, middle and recent) (Constantin 1985).

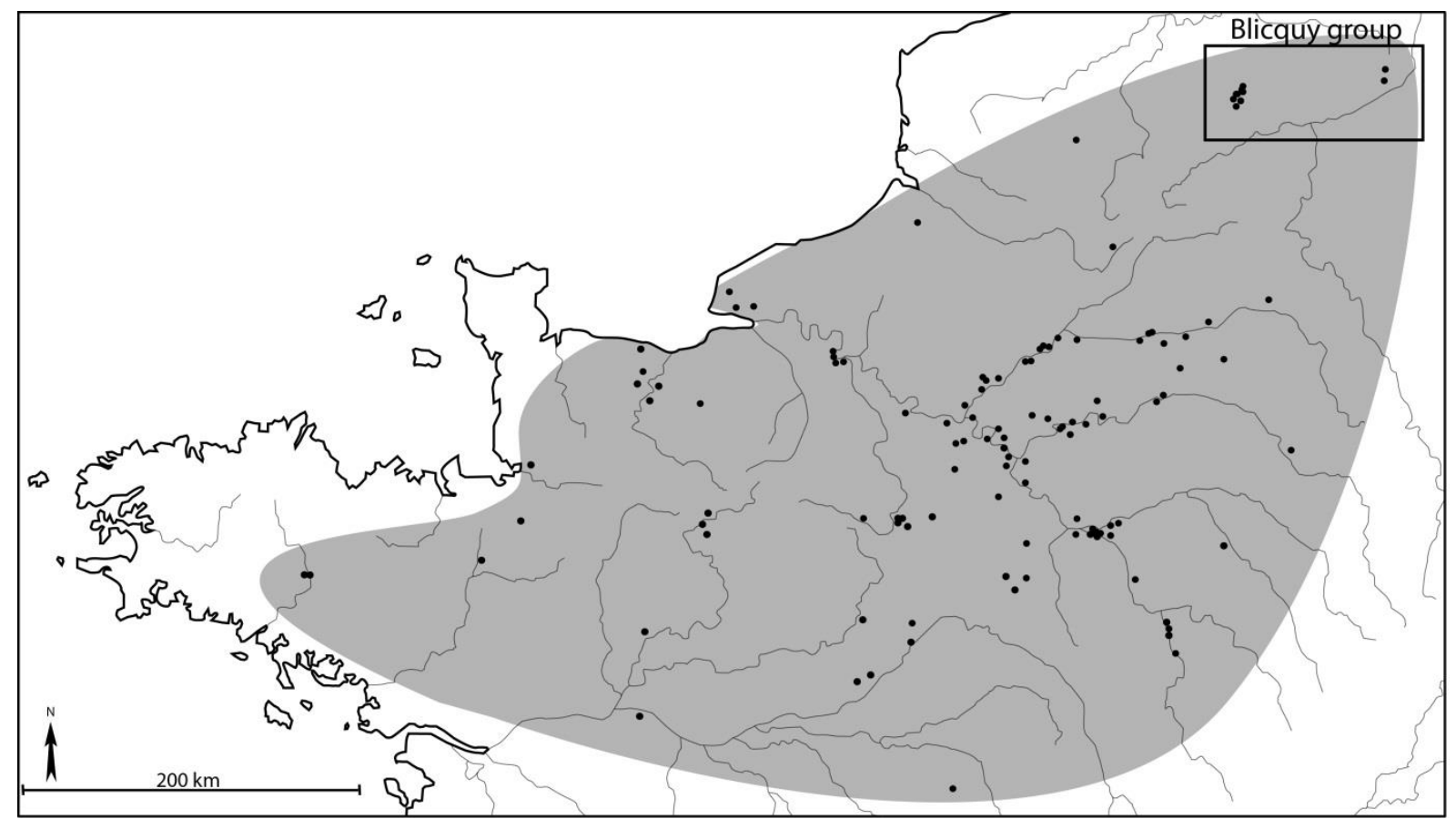

Figure 1. Map pointing the sites of the BQ/VSG culture. The sites located in Belgium constitute the BQ group.

The VSG sites correspond to the ones located in the North of France. More than 200 sites can be counted and lots of them were discovered during survey excavations. The lithic industry of VSG sites was the subject of several university works (Bostyn 1994; Allard, 1999; Augereau, 2004; Denis, 2012a) and is now well documented. The BQ sites are the 11 sites located in Belgium, with two main centers of occupation: a Western one in Hainaut and an Eastern one in Hesbaye, $100 \mathrm{~km}$ away from the first (Figure 1). The nine sites located in Hainaut have been dug in the 1970-80s. Except for the eponymous site (Blicquy "la Couture de la Chaussée", Cahen \& Van Berg 1979), the publications about the siliceous industry at those sites aren't really detailed. That's why our PhD deals with this industry. More recently, two sites have been dug in Hesbaye: Darion (Jadin et al. 2003) and Vaux-et-Borset (Caspar et al. 1993; Caspar \& Burnez-Lanotte 1994). Located on the fringe of the extension area of the BQ-VSG culture, the publications provide more information about the lithic industry.

\subsection{General characteristics of the BQ-VSG lithic industry}

The lithic industry of the BQ-VSG culture stands out by concomitant blade and flake production (Bostyn 1994; Caspar \& Burnez-Lanotte, 1994; Allard 1999; Jadin et al. 2003; Augereau 2004). The respective parts of both productions vary quite a lot from one region to the other, although the domestic flake production is systematically dominant. Blade production only represents $10-40 \%$ of the BQ-VSG assemblages.

It should be taken into consideration that the flakes and blades are not made by the same knappers (Augereau 2004). Flake production undeniably requires a lower level of skills than blade production given that it is made by hard percussion without initial preparing of the blocks, most often by linked sequences of unipolar debitage (Allard 1999).

The operational sequence of blade debitage is close to the one practiced by the Linear Pottery Culture. Shaping is made by creating one crest or more. Debitage, done by indirect 
percussion, is unipolar and semi-turning to turning. Generally, the striking platforms are faceted and the overhangs frequently prepared by slight abrasion. The desired blanks are regular, frequently trapezoidal blades, between 8 to $10 \mathrm{cms}$ long, 18 to $25 \mathrm{mms}$ wide and 4 to $6 \mathrm{mms}$ thick (Bostyn 1994; Allard \& Denis 2013). Furthermore, a production of long blades measuring up to $20 \mathrm{cms}$ long exists. This production was made from Bartonian flint (Bostyn, 1994) and seems to be produced specifically to be put in circulation (Denis, 2012a).

\subsection{Which raw materials are available?}

The identification of flints circulation is inevitably linked to the search for raw material sources. These sources are well documented for distinct sectors of the Paris Basin (see history for example in Allard et al. 2005; Allard et al. 2010). The region can be characterised by two major geological formations: the landscapes formed by Cretaceous White Chalk and the Tertiary plateau of Ile-de-France. The flint resources are abundant in the Upper Cretaceous (Turonian, Santonian, Coniacian, Campanian), in primary position in most of the sectors, as well as in the Eocene of the Tertiary basin. The Early Neolithic groups extensively exploited these sources.

In Belgium, the issue of flint sources is much more difficult to tackle given that there is currently not a single systematic reference collection. Nonetheless, a very general description of the flint sources is available (Cahen et al. 1986). The raw material in Belgium can be found in both Cretaceous areas identified in Belgium (Figure 2). The Danubian population of Hesbaye settled near these outcrops (Allard 2005; Caspar \& Burnez-Lanotte 1994). They mainly exploited two kinds of flints, macroscopically very different: the fine-grained flint of Hesbaye and the granular flint. The identification of raw materials was more complex in the Mons Basin, but given the fact that 22 Cretaceous formations are represented (Robaszynski et al. 2001), the possibilities are numerous. Traditionally, in the literature, 4 types of flint are mentioned: the Obourg flint, the Ghlin flint, the Turonian flint and the Spiennes flint (Allard 2005; Allard et al. 2010; Cahen \& Van Berg 1979; Cahen et al. 1986; Hubert 1982). The Danubian populations do not use the latter. The BQ industry of Hainaut shows a supply oriented toward the Ghlin flint which represents between 60 and $80 \%$ (Cahen \& Van Berg, 1979; Constantin 1985). Therefore, even if the outcrops are not clearly localized, one can rationally thinking that the Ghlin flint was gathered in the Mons Basin.

Despite the problems related to the identification of raw materials, two main circulation networks have been identified: one of tertiary Bartonian flint (Bostyn 2008) and one of Ghlin flint. These two types of flint are indeed easily recognizable by their macroscopic characteristics. The Bartonian flint was discovered at all the BQ sites (Caspar \& BurnezLanotte 1994; Jadin et al. 2003; Bostyn 2008). The circulation of tertiary Bartonian flint is now well-known and emblematic of the BQ -VSG culture (Bostyn 1994, 1997; Allard \& Bostyn 2006; Denis 2012a). As this circulation has been discussed many times, this paper will focus on the circulation of Ghlin flint. As mentioned earlier, the outcrops of Ghlin flint must be located in the Mons Basin, as testified by the important rates of this flint found at the sites located in Hainaut. The discoveries of Ghlin flint on the BQ-VSG sites show that the Ghlin flint circulates according to 2 opposite directions. One is oriented toward the VSG sites, so at 150-200 km away from the Hainaut sites. The second one is oriented toward the Hesbaye sites, so about $100 \mathrm{~km}$ Eastward. There is therefore no doubt that these 3 occupation areas are connected. The study of the circulation of the Ghlin flint can provide some information about the relationships between those 3 regions.

The opposite directions taken by this circulation of Ghlin flint is accompanied by a fundamental difference of the circulation modalities. 


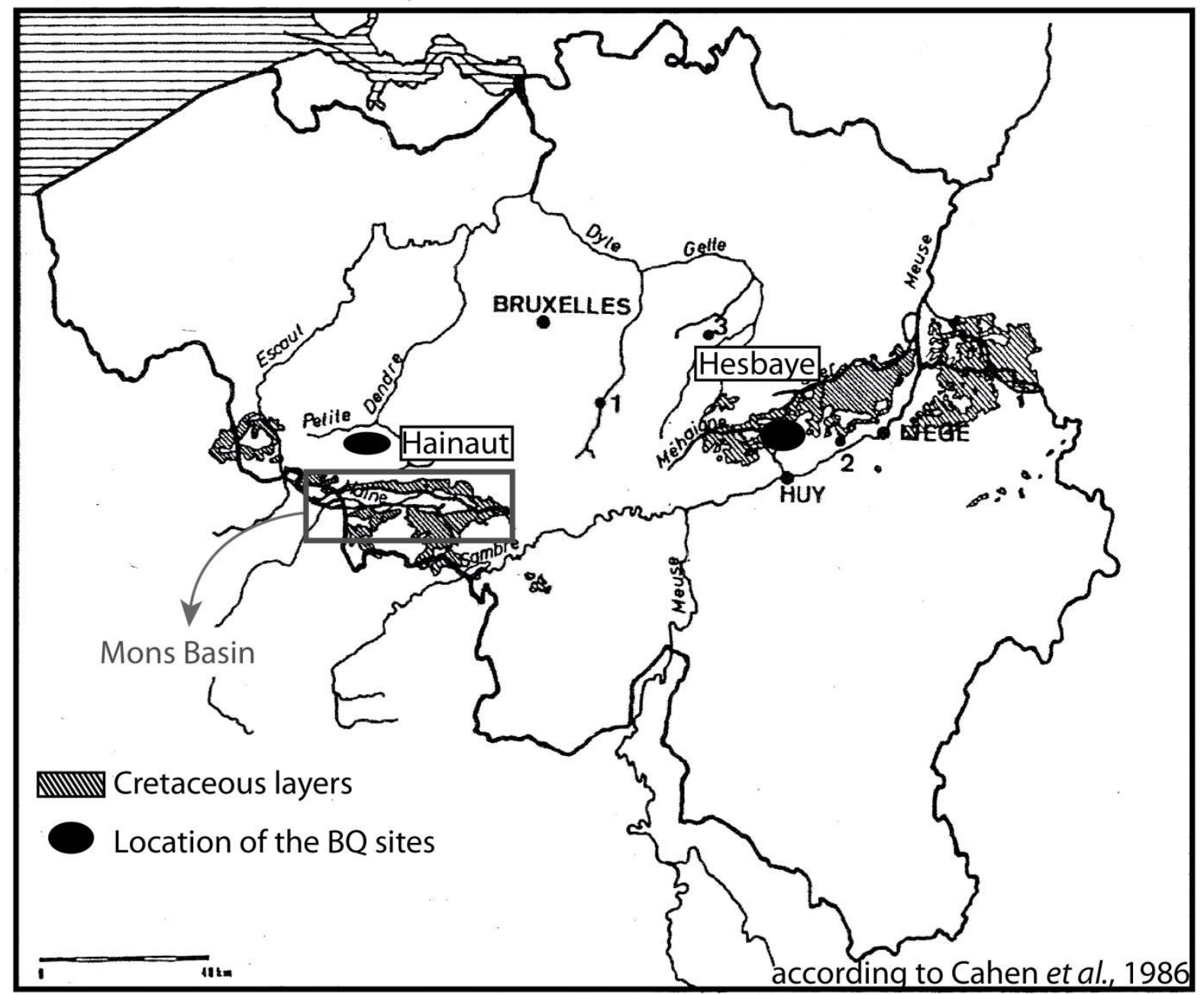

Figure 2. Location of the Cretaceous layers in Belgium that provide the siliceous raw materials exploited by the Early Neolithic population.

\section{The circulation of Ghlin flint toward the Paris Basin}

The literature shows that very few pieces of Ghlin flint have reached the Paris Basin. Seven VSG sites provide Ghlin flint (Table 1): Ocquerre (Praud et al. 2009), Vermand (Bostyn et al. 2003), Bucy-le-Long (Allard, 1999), Pontavert (Denis, 2012b), Lacroix-SaintOuen (Bostyn, 1994), Pontpoint (Bostyn et al. 2012) and Noyelles-sous-Lens (Martial, 2001 ; Praud et al. 2010). Generally, these pieces represent less than $0,1 \%$ of the corpus. On the site of Vermand, it represents nearby $2 \%$ but this site is not really representative because it has just delivered around 100 pieces. On the other hand, the site of Pontpoint appears to be particular because of its high number of blades found. The Ghlin flint comes from 2 of the 3 or 4 houses discovered on this village. It is concentrated in the house 50 which delivered $80 \%$ of the Ghlin flint (Bostyn et al. 2012). In this house, the rate of Ghlin flint reaches 1,6\%. In the second house (M. 60), it represents 0,6\%. Even if the number of Ghlin pieces discovered on those sites is really weak, Pontpoint appears like an exception with its higher rate. This site is the only attributed to the early stage of the BQ-VSG culture.

Nevertheless, the modalities of Ghlin flint circulation toward the VSG sites are similar. Only blades were moved. The only exception is Bucy-le-Long, where one polyhedron was discovered. This piece is related to the domestic production mentioned earlier. It seems that the tools were made on the VSG sites, at least it is the case on the site of Pontpoint where burin spalls were discovered (Bostyn et al. 2012). On the other sites, the tools are mainly 
retouched blades. Without sieving, the very little flakes produced by retouches are rarely discovered.

Table 1- Table that described the data of all the VSG sites which provided Ghlin flint.

\begin{tabular}{cccccc}
\hline site & department & $\begin{array}{c}\text { chronological } \\
\text { stage }\end{array}$ & $\begin{array}{c}\text { Ghlin } \\
\text { flint (nb) }\end{array}$ & $\begin{array}{c}\text { number total of } \\
\text { flints }\end{array}$ & type of pieces \\
\hline Ocquerre & Seine-et-Marne & recent & 1 & 16737 & blade \\
Vermand & Aisne & indeterminate & 2 & 105 & blades \\
Bucy-le-Long & Aisne & recent & 4 & 5413 & 3 blades+ 1 polyhedron \\
Pontavert & Aisne & middle/recent & 1 & 374 & blade \\
Lacroix-Saint-Ouen & Oise & recent & 1 & 1560 & blade \\
Pontpoint & Oise & early & 45 & 4776 & blades \\
Noyelles-sous-Lens & Pas-de-Calais & indeterminate & 1 & indeterminate & blade \\
\hline
\end{tabular}

The products in circulation are mostly regular and trapezoidal blades coming from the full time of the debitage, so these blades are selected to be put in circulation. Bucy-le-Long is again an exception because one of the blades comes from the flank of the core (Figure 3). So it appears that the selection of the products in Bucy-le-Long is less rigorous than at the other sites.

\section{$10 \mathrm{~cm}$}

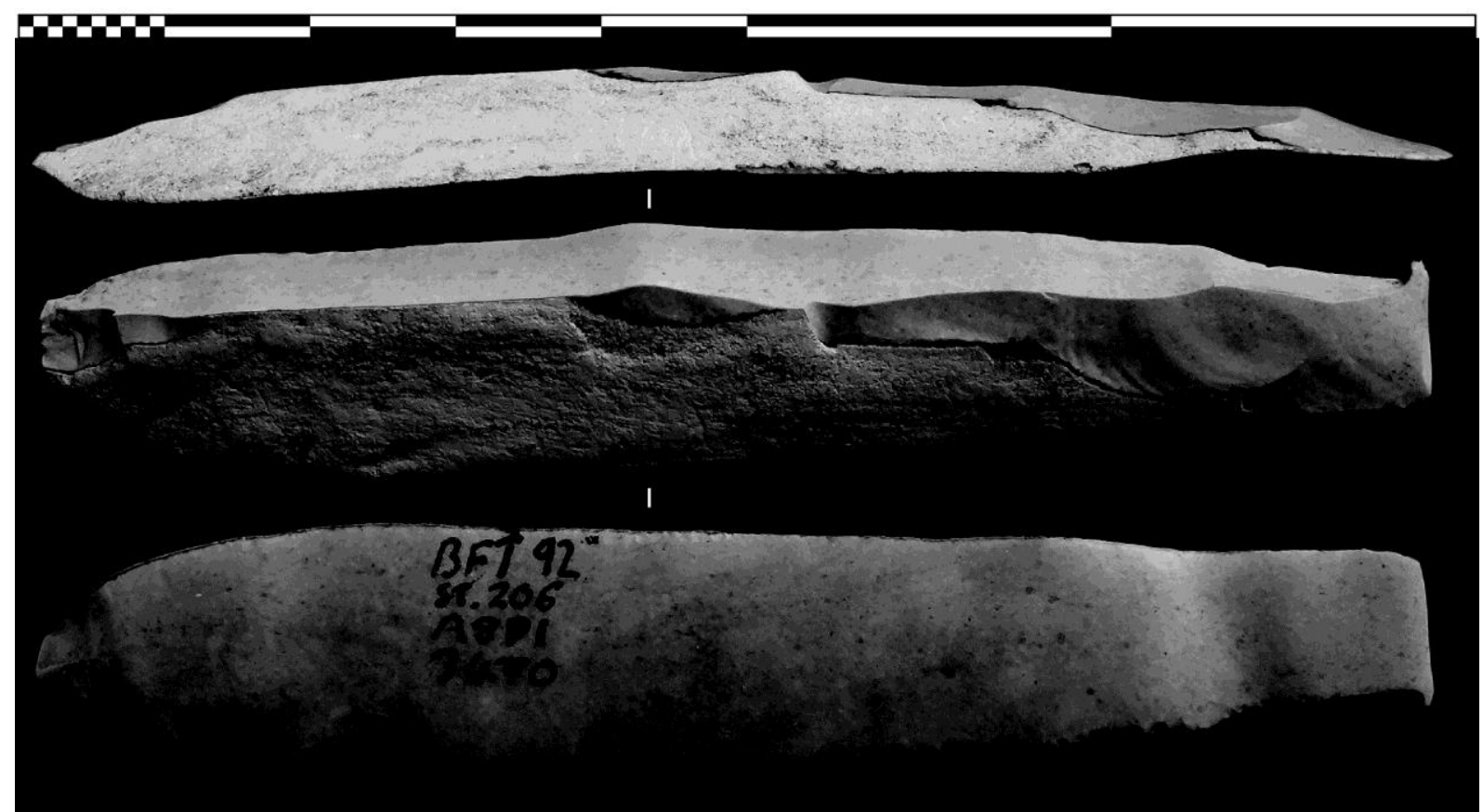

Figure 3. Photograph of one flank blades in Ghlin flint discovered in Bucy-le-Long "la Fosse Tounise" (Aisne).

To sum up, the Ghlin flint circulates toward the Paris Basin under the form of blades. The debitage never took place on the VSG sites. Furthermore, it seems that there is a clear selection of the products put in circulation. The site of Pontpoint delivers a lot of blades and is dated from the very beginning of the BQ-VSG culture. The circulation of Ghlin flint appears to be very different looking in the other direction, toward the Hesbaye region. 


\section{The circulation of Ghlin flint Eastward: The case of Vaux-et-Borset and Darion (Hesbaye)}

The two blicquian sites situated in Hesbaye, $100 \mathrm{~km}$ away from the outcrops, deliver low quantities of Ghlin flint (Table 2). These sites have been attributed to the middle stage of the BQ-VSG culture (Jadin et al. 2003; Caspar \& Burnez-Lanotte, 1994).

Table 2- Number of pieces in Ghlin flint discovered on the BQ sites of Hesbaye.

\begin{tabular}{lcc}
\hline & number of Ghlin pieces & total number of flints \\
\hline Vaux-et-Borset & 1686 & 39645 \\
Darion & 5 & 1655 \\
total & 1691 & 41300 \\
\hline
\end{tabular}

\subsection{The case of Vaux-et-Borset}

The site of Vaux-et-Borset appears to be unique in terms of circulation of the Ghlin flint. The lithic industry of Vaux-et-Borset was the subject of many publications (Caspar \& Burnez-Lanotte 1994, 1996, 1997, 2003, 2008). That's why our study of this site is concentrated on two unpublished structures excavated in 1998 (Caspar et al. 1999). Wellpreserved, they deliver around 7000 pieces of flint concentrated in one of these structures. Their characteristics attest that they are lateral pits from a house. To precise the circulation networks of flints, the exogenous raw materials of all the structures of Vaux-et-Borset have been studied too.

\subsubsection{General characteristics of the lithic industry of Vaux-et-Borset}

In Vaux-et-Borset, the raw materials are mostly local (Figure 4). They represent around $80 \%$ of the material. The fine-grained flint of Hesbaye is the most exploited. The Ghlin flint represents $7 \%$ of the corpus. It is significant especially as it is the second most represented flint in number. The presence of Ghlin flint is even more significant according to the examination of the productions.

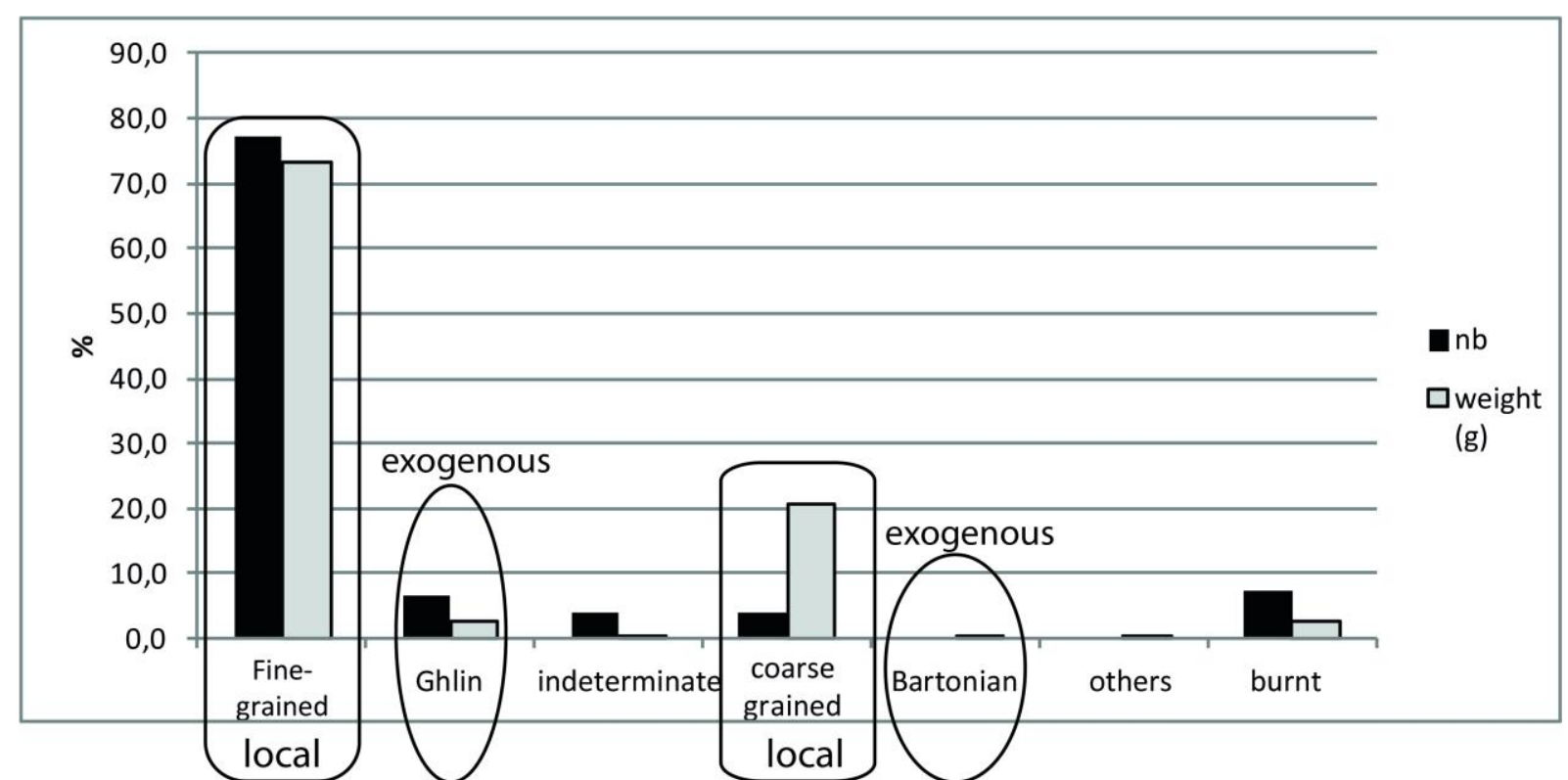

Figure 4. Siliceous raw materials spectrum of Vaux-et-Borset, from the two pits excavated in 1998 which delivered 6968 pieces (62 500g). 
As developed earlier, the lithic industry of the BQ-VSG populations is characterized by a duality of the productions. In Vaux-et-Borset, this regularity is also observed. The flakes production is widely dominant $(90 \%)$. This percentage includes also a facetted tools production, which was not systematically identified in the VSG industry but often discussed.

The classification by productions coupled with the analysis of the raw materials shows that flakes and facetted tools are mostly produced from local raw materials (Figure 5). On the contrary, the exogenous raw materials are exploited for the production of blades. It seems quite obvious that the Ghlin flint is important for the inhabitants of Vaux-et-Borset because it is the most employed to produce blades (Figure 6). This data demonstrate the strong link existing between Hainaut and Hesbaye.

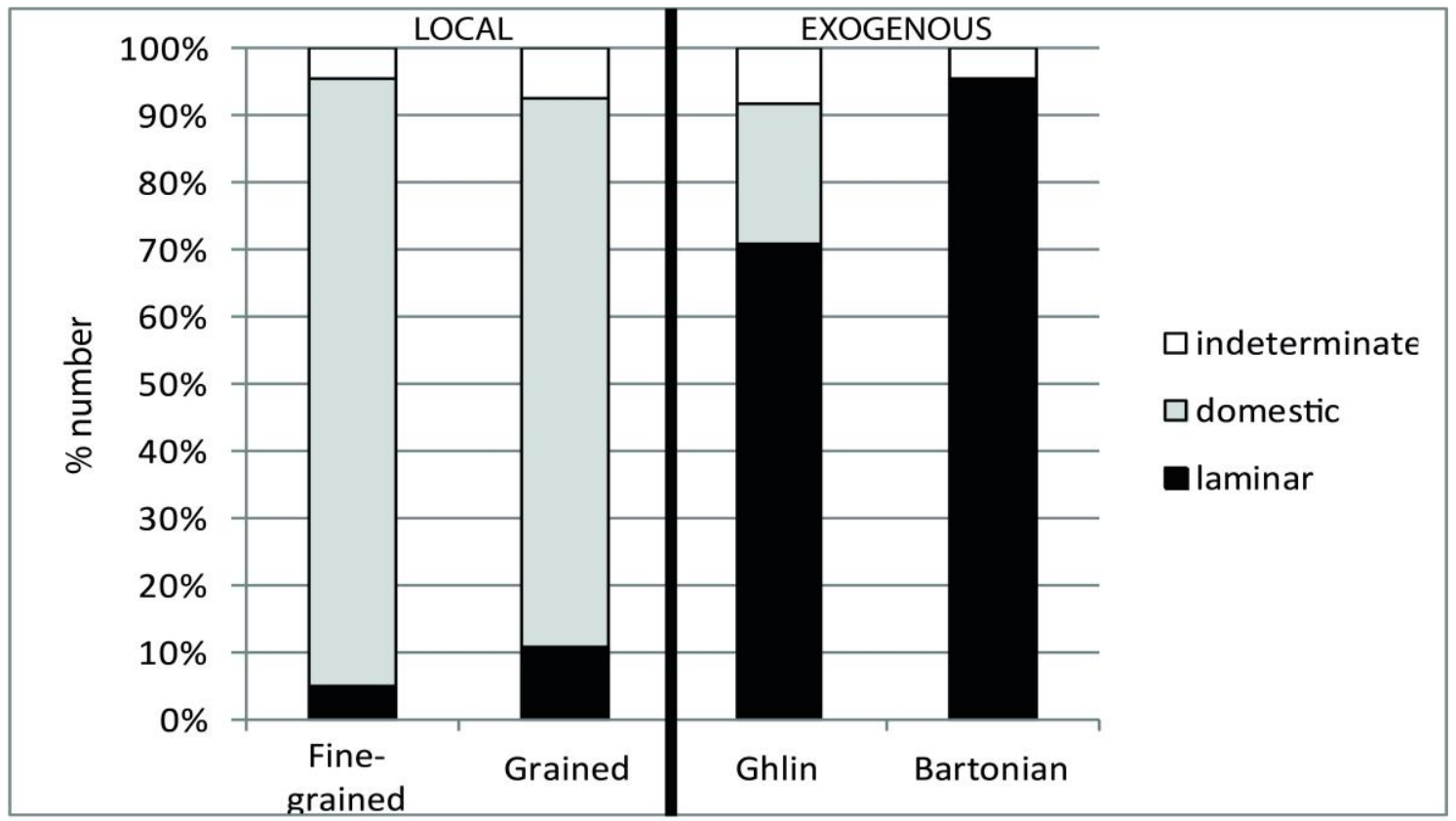

Figure 5. Representation of the part of the different productions according to the different raw materials exploited.

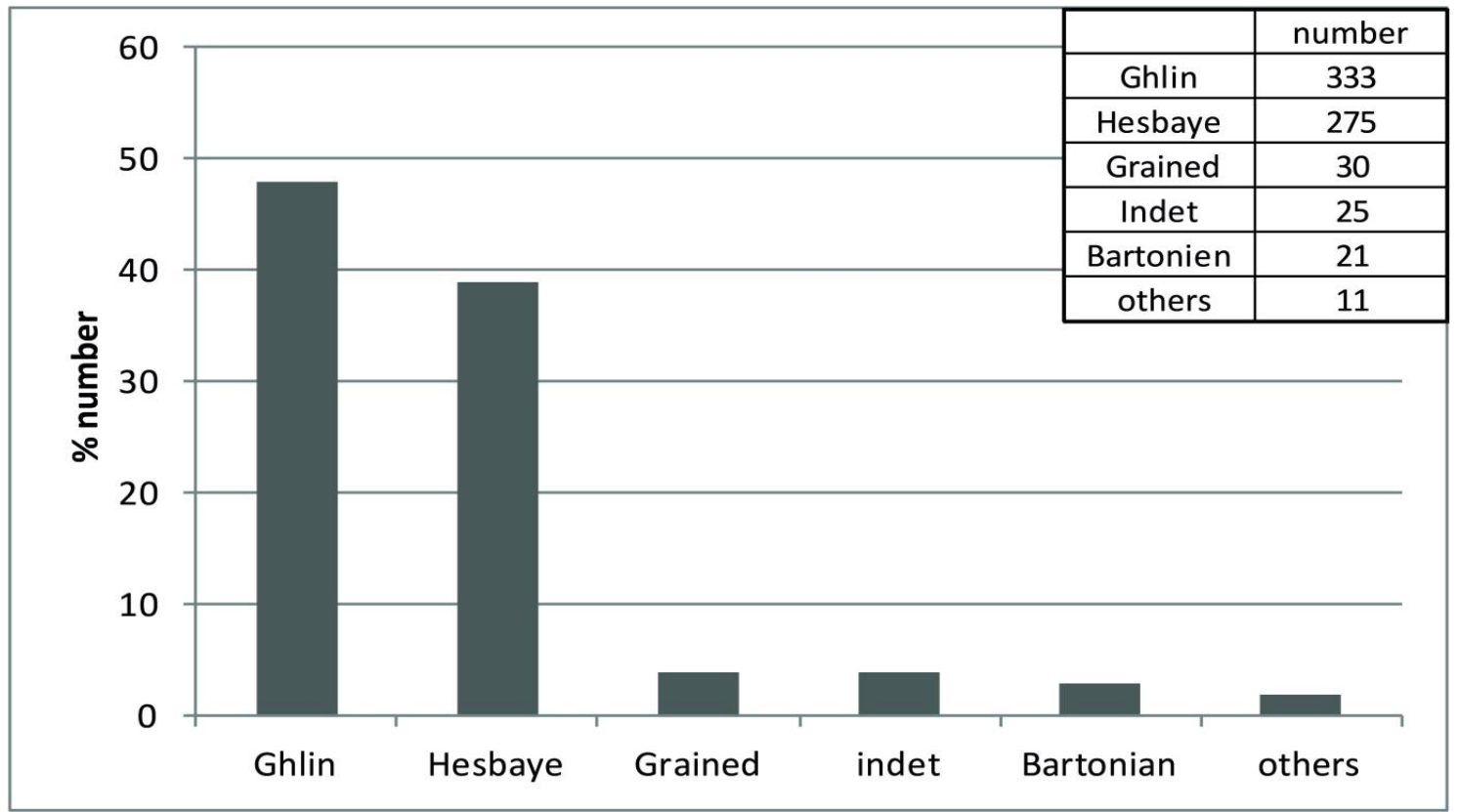

Figure 6. Laminar production. Count of the pieces attributed to the laminar production by raw materials. 


\subsubsection{Modalities of circulation of the Ghlin flint}

The construction of the techno-economical diagram aims at visualizing the quantitative representation of each step of the chaîne opératoire of the blades production. The lecture of this diagram shows that the production took place in situ starting from untreated blocks or slightly preformed blocks (Figure 7). Nevertheless, even if it is difficult to demonstrate, it is possible that several blades were circulating simultaneously. The presence of a very long blade, which contrasts with the rest of the production, is a clue.

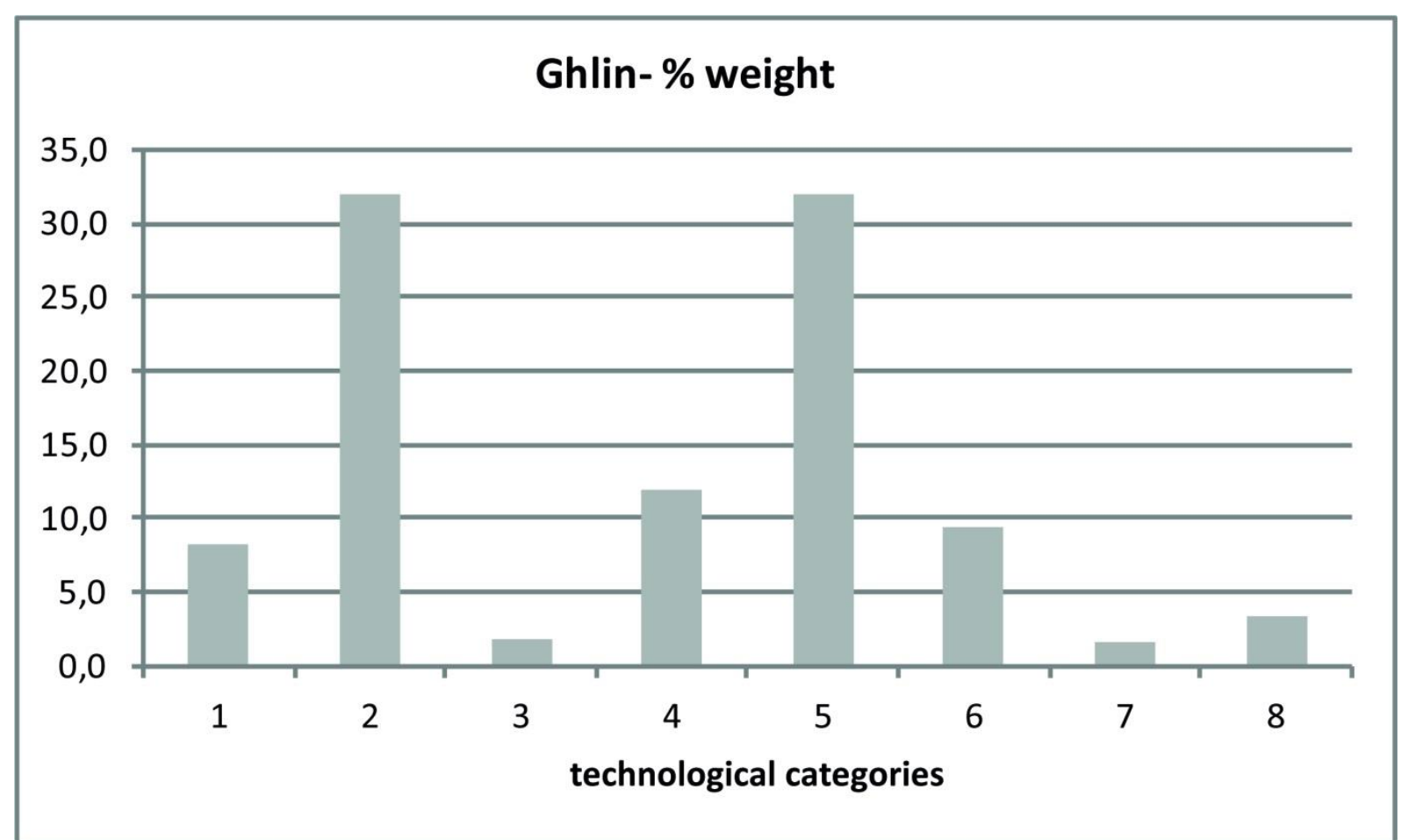

Figure 7. Techno-economical diagram of the laminar production in Ghlin flint (in weight, g). 1. big flakes of the beginning of the shaping out, 2. flakes coming from the preparation of the crests, 3. crests, 4 . maintenance flakes of the debitage, 5. blades, 6. flakes attributed to the blades production but which can't be precisely replaced in the chaîne opératoire, 7 . very little flakes that those produced by retouches and the tools spall, 8 . final waste of the production which are the cores and the flakes from the recovery of the cores. Based on 1221 pieces (4823 g).

Two ways have been investigated to try to determine how many blocks were put in circulation. First, the number of crests was counted. In addition, to compare similar places on the different blocks, the refitting of the flakes coming from the preparation of the crests were taken into account. The macroscopic characteristics of the raw materials of these refitting have been compared in order to determine if they come from the same core or from different cores. Seventeen crests have been identified and at least 13 blocks using the refitting can be distinguished. Given the fact that it seems that most of the cores are prepared with only one crest, it can be said that around 15 blocks of Ghlin flint have been circulated between the Hainaut and Vaux-et-Borset.

Thus, there is a clear difference in the circulation modalities of the Ghlin flint between Vaux-et-Borset and the Paris Basin. Not only blades but around 15 blocks of Ghlin flint have been transported from Hainaut to Vaux-et-Borset in order to produce blades. It is possible that several blades were carrying along with these blocks. In addition, several little blocks have been reserved for domestic productions. Given that the production was conducted locally, it is possible to wonder who the knappers of this production are. 


\subsubsection{Who are the knappers of the Ghlin flint production?}

The laminar production made of Ghlin flint took place in the village of Vaux-et-Borset. It is possible to establish comparisons between this production and the one in local raw materials. Several publications have underlined the differences between the blades in exogenous raw materials and the blades in local raw materials (Caspar \& Burnez-Lanotte 1994, 1997). The authors wrote that there is not enough waste of the laminar production in local raw material to make sure that the production took place in the villages. Furthermore, the characteristics of the local blades are very different and close to the laminar production done during the Linear Pottery Culture. The authors then proposed that the blicquian population made a recycling of the Linear Pottery Culture objects for they own use. We will not here develop the other arguments presented and we won't reject this hypothesis. However, in the structures we studied, other results appear. It needs to precise that these structures are the most remote from the Linear Pottery Culture village.

For these structures the establishment of a techno-economical diagram led us to assure that the laminar productions in local raw materials were made locally (Figure 8). The configuration of the diagram is quite conform to what one could expect if the chaîne opératoire was conducted in or close to this house. Admittedly, the very low output of the production raises issues that we will not be discussed here. Since both productions (exogenous and local raw materials) have been conducted locally, it is possible to establish comparisons in order to determine if the knappers are the same. In agreement with the previous publications, many differences can be underlined between the blades made of the fine-grained flint of Hesbaye and those made of Ghlin flint. The corpus of blades made of coarse-grained flint is too insignificant to be exploited here.

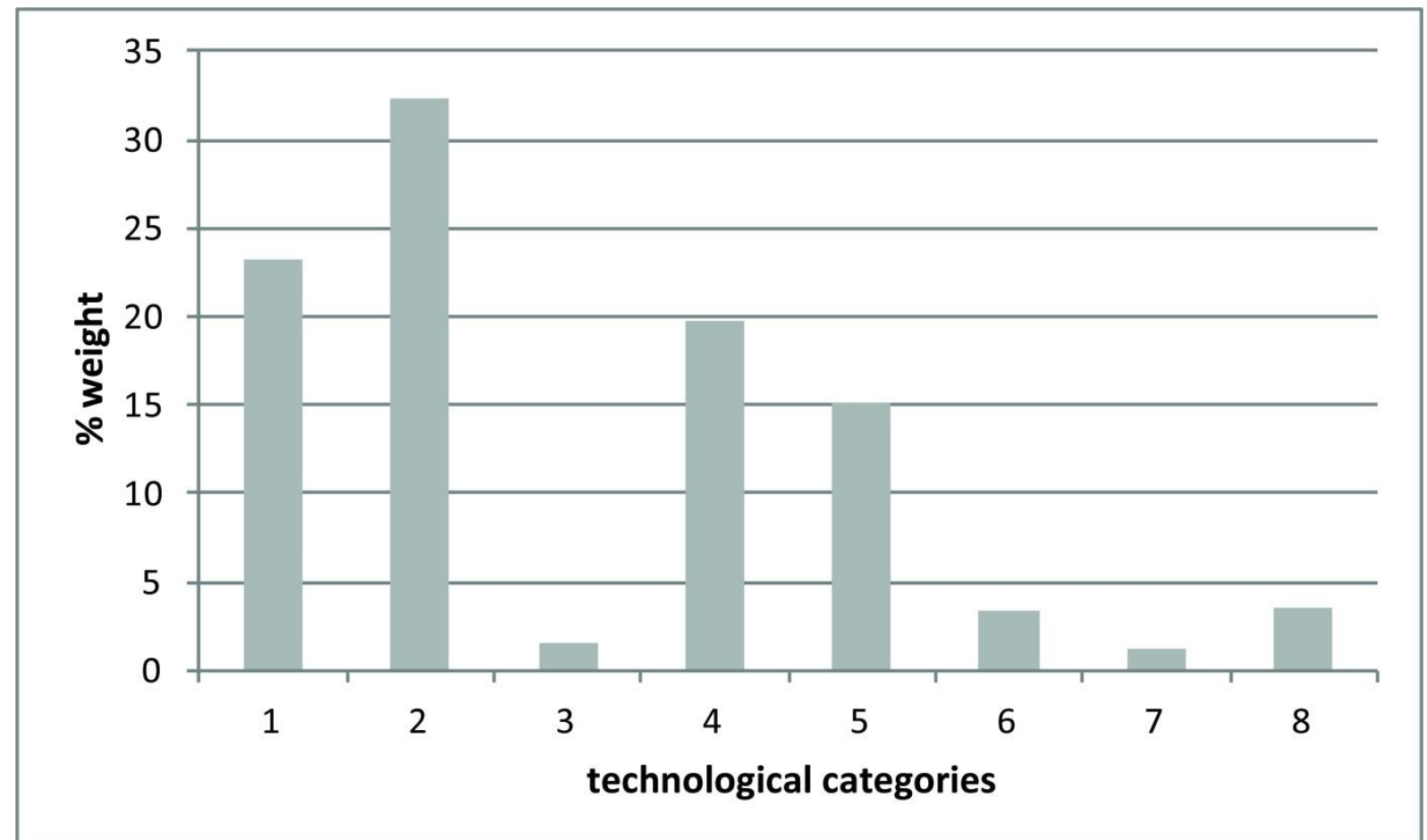

Figure 8. Techno-economical diagram of the laminar production in fine-grained flint from Hesbaye (in weight, g). 1. big flakes of the beginning of the shaping out, 2. flakes coming from the preparation of the crests, 3. crests, 4. maintenance flakes of the debitage, 5. blades, 6. flakes attributed to the blades production but which can't be precisely replaced in the chaîne opératoire, 7. very little flakes that those produced by retouches and the tools spall, 8. final waste of the production which are the cores and the flakes from the recovery of the cores. Based on 275 pieces $(1674 \mathrm{~g})$. 
First, the length of the blades differs slightly. The blades which are made of Ghlin flint are slightly longer than ones that are made of fine-grained flint (Table 3). Then, the sections differ clearly (Figure 9). The Hesbaye blades are either triangular (2 facets) or trapezoidal (3 facets) while the Ghlin blades are preferentially trapezoidal. In terms of regularity, it appears that the Ghlin blades are more regular $(85 \%)$ than the Hesbaye blades $(68 \%)$. The observation of the butts of the blades are very conclusive. There is a clear difference on the dimensions of the butts. The Ghlin blades have smallest butts than the Hesbaye blades (Figure 10). Furthermore, the morphology of the butts differs between those two kinds of blades and it is directly connected to the way the debitage preparation was done. The majority of the pieces have flat butts but they are more numerous for the Hesbaye blades (80\% against $60 \%$ for the Ghlin flint). The Ghlin flint blades show more dihedral butts $(36 \%)$ than the Hesbaye blades $(13 \%)$. This kind of butt signals directly that the striking platforms are facetted. This preparation seems to be more frequent in the Ghlin production.

Table 3- Average lenght (in $\mathrm{mm}$ ) of the blades in fine-grained flint of Hesbaye and in Ghlin flint. This average is calculating on the minimal number of blades which is obtained by the number of proximals.

\begin{tabular}{lcc}
\hline & Ghlin & fine Hesbaye \\
\hline total lenght $(\mathrm{mm})$ & 13119 & 2325 \\
number of proximal & 146 & 34 \\
average lenght $(\mathrm{mm})$ & \pm 90 & \pm 68 \\
\hline
\end{tabular}

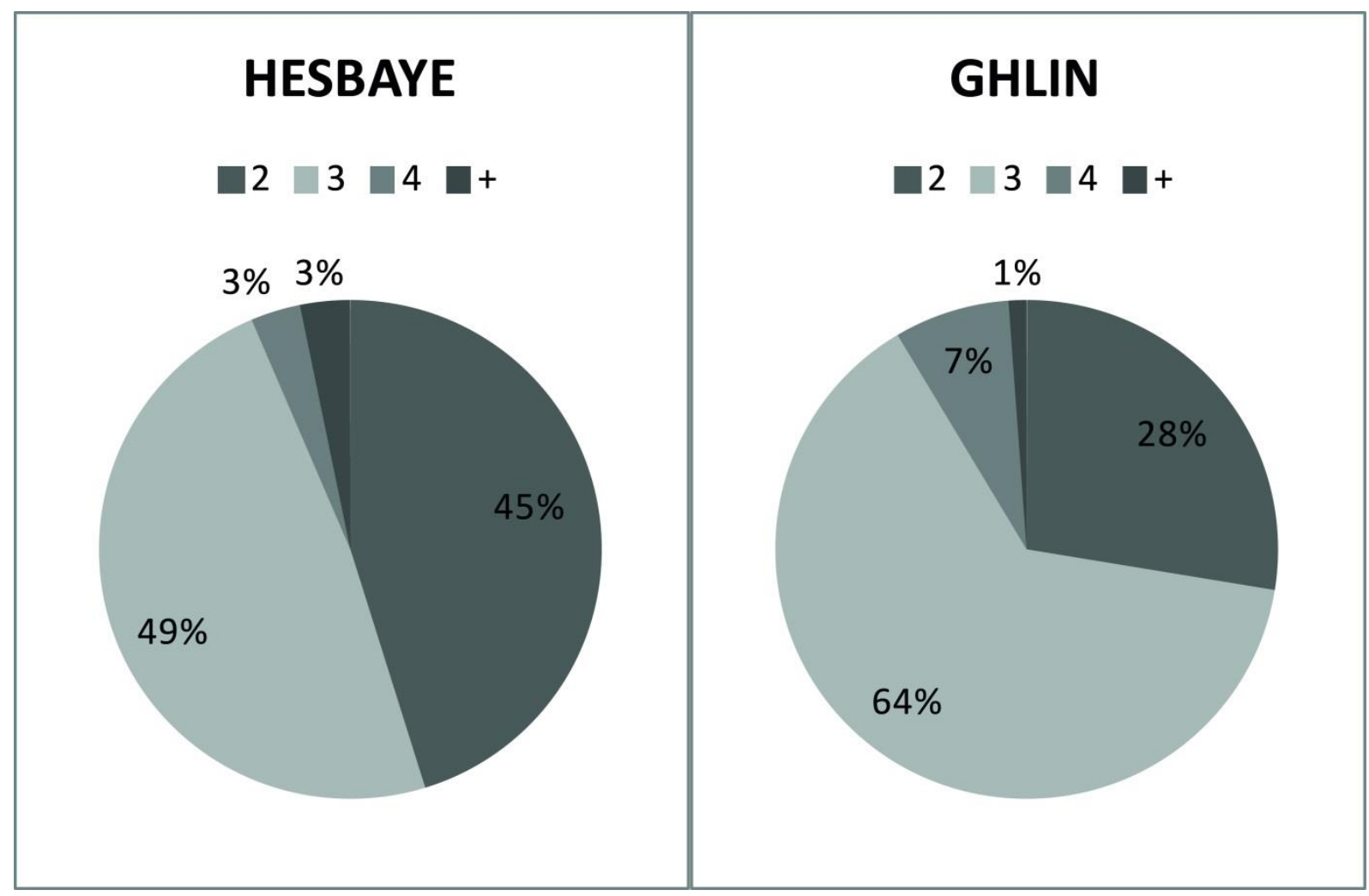

Figure 9. Comparisons between the sections of the blades in Ghlin flint $(n=174)$ and in fine-grained flint of Hesbaye ( $\mathrm{n}=31$ ). $2: 2$ facets (triangular blades), $3: 3$ facets (trapezoidal blades), $4: 4$ facets, $+: 5$ facets and more. 

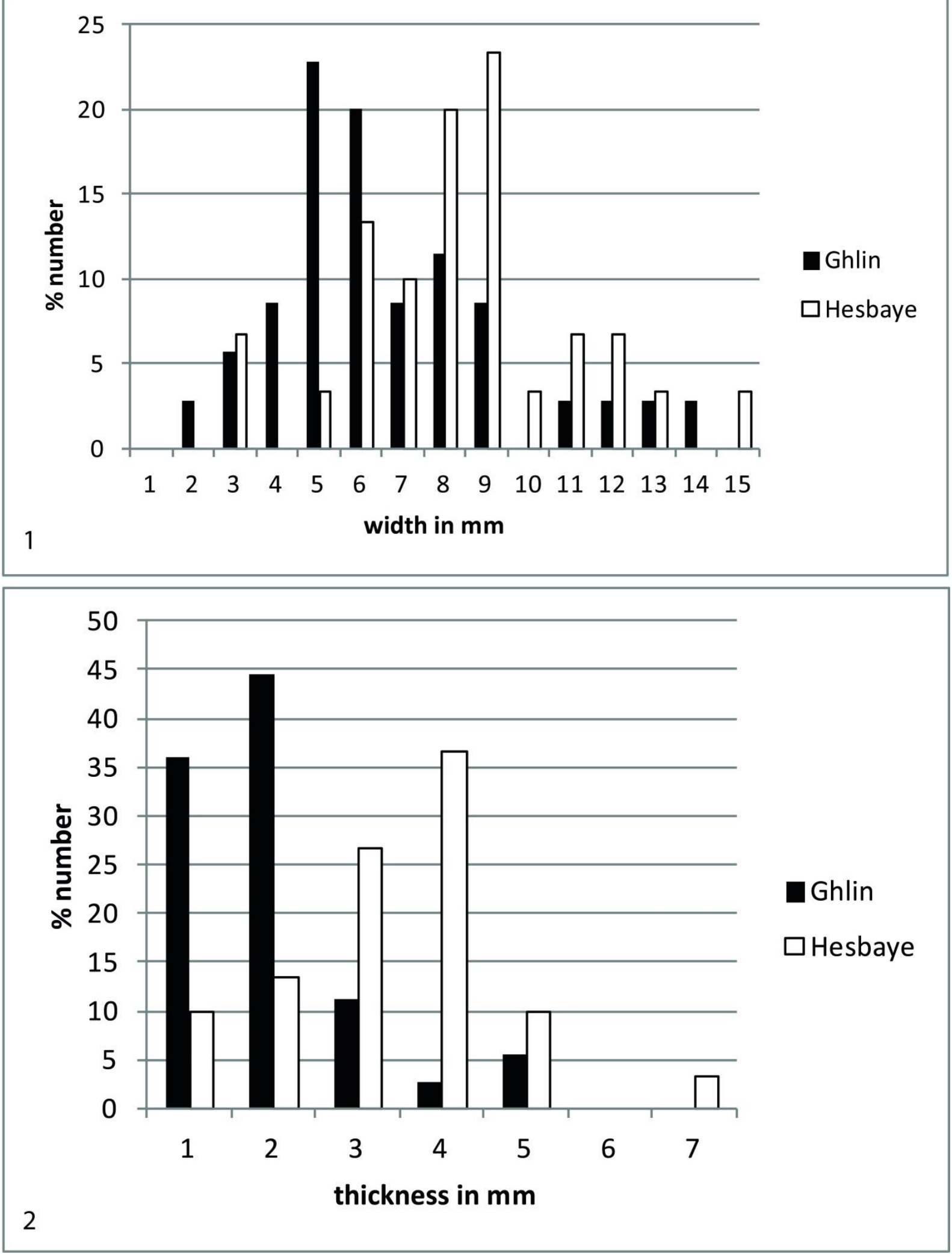

Figure 10. Comparisons between the dimensions of the butts, blades from VCM 98, 35 blades in Ghlin flint and 30 blades in fine-grained flint of Hesbaye. 1. width in $\mathrm{mm}$; 2. thickness in $\mathrm{mm}$.

All those differences allow us to conclude that the knappers are not the same for the Ghlin flint productions and for the production made of the fine-grained flint of Hesbaye. The latter seems to be characterized by a low level of how-know. An opposition in the technical 
tradition can also be suggested. Indeed the first observations made on the blade production at the Hainaut sites show that the characteristics observed on the blades made from the finegrained flint of Hesbaye do not appear there (Denis, $\mathrm{PhD}$ in course). This information tends to prove the existence of moving knappers between Hainaut and Hesbaye.

\subsection{The case of Darion}

In Darion, five pieces made of Ghlin flint can be counted, which represents less than 0,5 $\%$ of the corpus (Jadin et al. 2003). Furthermore, it seems that they weren't produced on the site, or just partially. Four of the pieces are blades. There is just one maintenance flake.

So, the Ghlin flint is circulated under the form of blades. Maybe one core in the process of debitage could have been introduced too. Three of the blades are blades coming from the flank of the core. Among them, one shows the negatives of a crest. The corpus is really limited so it is difficult to make the comparisons that were done in Vaux-et-Borset, but it seems that the characteristics of the products are close to those observed in Vaux-et-Borset. One blade is entire and measures $92 \mathrm{~mm}$. All the blades are trapezoidal. Two of these pieces have their butt. One is flat but the other is dihedral. The latter have bigger dimensions than the flat one which measures $5 \times 2 \mathrm{~mm}$.

It seems that the circulation of Ghlin flint toward the site of Darion follows other modalities than in Vaux-et-Borset. The Ghlin flint is circulated under the form of blades. It is possible that one core in process of debitage was introduced too. But unlike Vaux-et-Borset, it is evident that all the debitage doesn't take place in situ. The selection of the blades to be put in circulation toward the site of Darion is less stringent than toward the Paris Basin. The characteristics observed on these blades are quite similar to those of the Ghlin flint blades of Vaux-et-Borset.

\section{Conclusion}

This short examination of the circulation of Ghlin flint led us to oppose two modalities of circulation (Figure 11). First, the Ghlin flint is circulating under the form of blades toward the Paris Basin. It seems that this circulation started at the beginning of the BQ-VSG culture, as testified the site of Pontpoint. Furthermore, the high quantity of blades discovered in Pontpoint is remarkable compared to the other sites. According to the research done so far, none of the VSG sites attributed to the middle stage of this culture provided Ghlin flint. In the other hand, the two sites from the Hesbaye region are dated from this middle stage. The Ghlin flint circulation toward these sites seems to be completely different from the circulation toward the Paris Basin. Indeed, in Vaux-et Borset, around 15 untreated or slightly preformed blocks were introduced to be exploited in the village. Furthermore, the characteristics of the Ghlin blades are so different compared to the blades made from local raw materials that it is possible to conclude that the two sets of blades were produced by different knappers. The skills involved in the production of blades made from local materials seem to be lower than the ones involved in the production of Ghlin blades, which is probably coupled with a difference in terms of technical tradition. The first conclusions drawn from the observation of the Hainaut sites production show that the characteristics of the fine-grained flint of Hesbaye don't exist on the Hainaut sites. If it is confirmed, it means that there are two technical traditions and that the production made of Ghlin in Vaux-et-Borset is made by knappers from the Hainaut villages. So the linkages between Hainaut and Hesbaye seem to be intenser than with the Paris Basin. The circulation of Ghlin flint is not an economic necessity. Lots of raw materials are available in Paris Basin and Hesbaye. Furthermore, the tools made on the Ghlin products don't distinguish themselves from those made in the other raw materials. Nevertheless, Vaux-et-Borset is again an exception because a very particular tool is 
exclusively made on exogenous raw materials like Ghlin flint or Bartonian flint (Caspar \& Burnez-Lanotte 2008). This tool seems to be directly connected to the schist bracelets production. So, to have a better understanding of the circulation of flints during the BlicquyVilleneuve-Saint-Germain culture, it is necessary to cross the data coming from the different activities spheres.

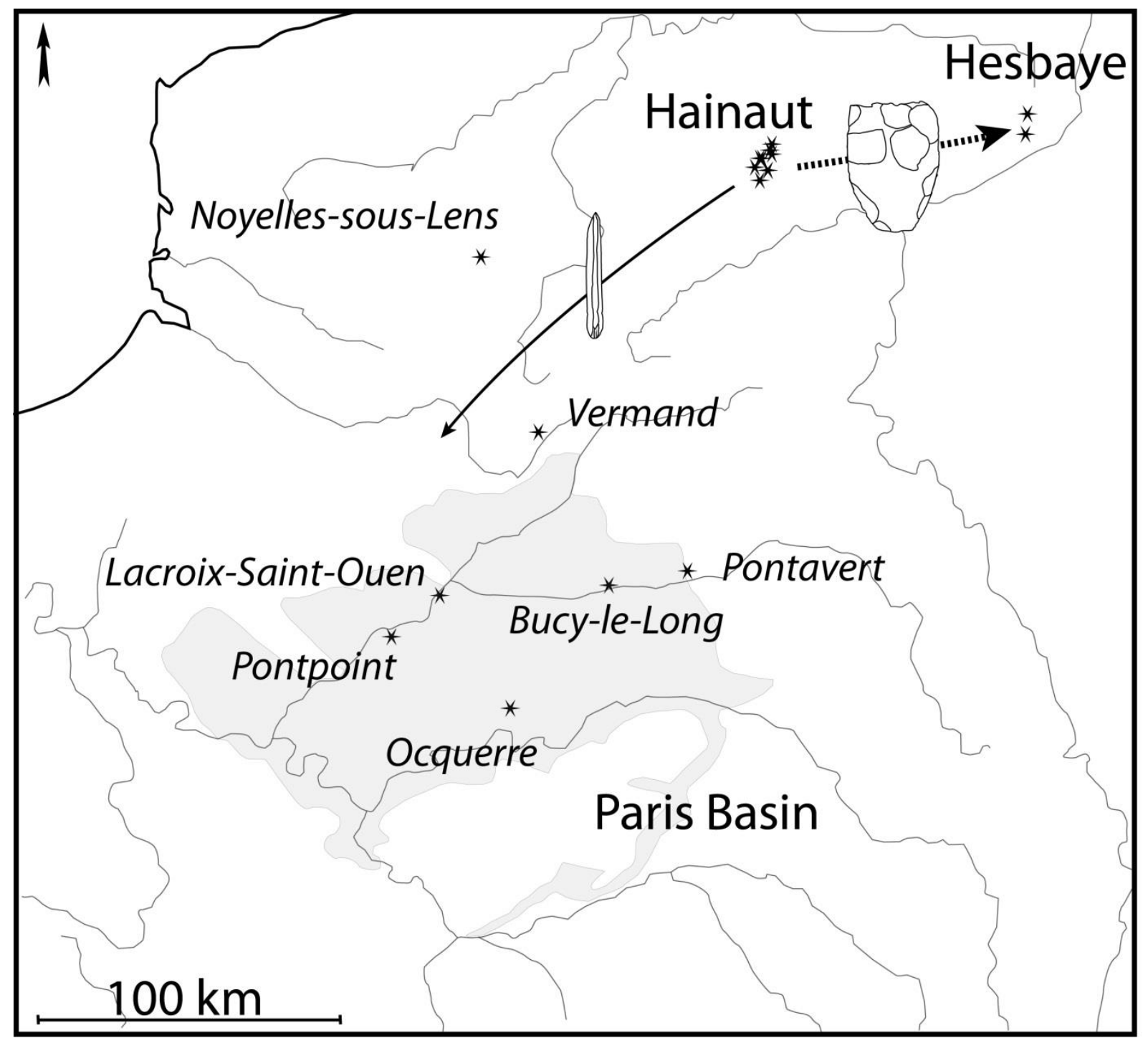

Figure 11. Schematic map of the circulation of Ghlin flint: sites concerned and opposition on the circulation modalities.

\section{Acknowledgments}

I would like to thank the Cercle archéologique Hesbaye-Condroz and his president E. Delye for having made available for me the complete lithic industry of Vaux-et-Borset. It is furthermore a pleasure to thank Professor Laurence Burnez-Lanotte for her welcome in the University of Namur (LIATEC laboratory) where she gave me the best conditions to study this site of Vaux-et-Borset. My gratitude also goes to M. Ivan Jadin for allowing me access to the material of Darion and so warmly received in the Royal Institute of Natural Sciences of Belgium. 


\section{References}

Allard, P. 1999, L'industrie lithique du groupe de Villeneuve-Saint-Germain des sites de Bucy-le-Long (Aisne). Revue Archéologique de Picardie, 3-4: 53-114. (in French) ("The lithic industry of the Villeneuve-Saint-Germain sites of Bucy-le-Long (Aisne)") doi:10.3406/pica.1999.2216

Allard, P. 2005, L'industrie lithique des populations rubanées du Nord-Est de la France et de la Belgique. Rahden, Verlag Marie, Leidorf, 242 p. (in French) ("The lithic industry of Bandkeramik populations in north-east France and Belgium")

Allard, P., Bostyn, F., \& Fabre, J. 2005, Origine et circulation du silex durant le Néolithique en Picardie : des premières approches ponctuelles à une systématique régionale. In: Hommages à Claudine Pommepuy, (Auxiette G. \& Malrain F., Eds.), Revue archéologique de Picardie numéros spéciaux Vol. 22, Amiens: p. 59-74. (in French) ("Origin and circulation of flint during the Neolithic in Picardy: first punctual approaches to a regional systematic") doi:10.3406/pica.2005.2721

Allard, P., \& Bostyn, F. 2006, Genèse et évolution des industries lithiques danubiennes du Bassin parisien. In: Contribution des matériaux lithiques dans la chronologie du Néolithique ancien et moyen en France et dans les régions limitrophes, (Allard, P., Bostyn, F. \& Zimmermann, A., Eds.), BAR International Series Vol. 1494, Archaeopress, Oxford: p. 28-52. (in French) ("Genesis and evolution of the Danubian lithic industries of Paris Basin")

Allard, P., Bostyn, F., Martial, E., Fabre, J., \& Collet, H. 2010, Les matières premières siliceuses exploitées au Néolithique moyen et final dans le Nord et la Picardie (France). In: Premiers Néolithiques de l'Ouest : Cultures, réseaux, échanges des premières sociétés néolithiques à leur expansion, 28e colloque interrégional sur le Néolithique, (Billard, C., \& Legris, M., Eds.), Presses Universitaires de Rennes, Rennes: p. 347-376. (in French) ("The siliceous raw materials exploited in the middle and final Neolithic in the North and Picardy (France)")

Allard, P., \& Denis, S. 2013, Origine et fin des traditions danubiennes : l'industrie lithique du Néolithique ancien de la vallée de l'Aisne. In chapter: Autour du Néolithique ancien. Les outils du changement : critique des méthodes (Session H), (Perrin, T., Manen, C., Marchand, G., Allard, P., Binder, D., Ilett, M., Chapter Eds.), In: Transitions, ruptures et continuité durant la Préhistoire, Actes du 27e Congrès préhistorique de France (Bordeaux - Les Eyzies, 2010), (Jaubert, J., Fourment, N., \& Depaepe, P., Eds.), Société préhistorique française, Paris: p. 465-483. (in French) ("Origin and ending of the Danubian traditions: the lithic industry of the Early Neolithic period of the Aisne valley")

Augereau, A. 2004, L'industrie du silex du Ve au IVe millénaire avant J.-C. dans le sud-est $d u$ Bassin parisien, Documents d'Archéologie Française Vol. 97, Éditions de la Maison des Sciences de l'Homme, Paris, 220 p. (in French) ("The industry of the flint from the 5 th to the 4th millennium BC in the southeast of Paris Basin")

Bostyn, F. 1994, Caractérisation des productions et de la diffusion des industries lithiques du groupe néolithique du Villeneuve-Saint-Germain. Unpublished $\mathrm{PhD}$ thesis, University of Paris X Nanterre. (in French) ("Characterization of the productions and diffusion of the lithic industry of the Villeneuve-Saint-Germain group")

Bostyn, F. 1997, Characterization of Flint Production and Distribution of the Tabular Bartonian Flint during the Early Neolithic (Villeneuve-Saint-Germain Period) in 
France. In: Man and Flint, (Schild, R. \& Sulgostowska, Z., Eds.), Institute of Archaeology and Ethnology, Polish Academy of Sciences, Warsaw: p. 171-183.

Bostyn, F. 2008, Les importations en silex bartonien du Bassin parisien sur les sites blicquiens en Hainaut belge. In: Fin des traditions danubiennes dans le Néolithique du Bassin parisien et de la Belgique (5100-4700 av. J.-C), Autour des recherches de Claude Constantin, (Burnez-Lanotte, L., Ilett, M., \& Allard, P. Eds.), Mémoire 44 de la SPF, Presses Universitaires de Namur, Namur, Société préhistorique française, Paris: p. 397-412. (in French) ("The imports in Bartonian flint of Paris Basin towards the blicquian sites of Hainaut (Belgium)")

Bostyn, F., Lemaire, P., \& Prodéo, P. 2003, Du Villeneuve-Saint-Germain/Blicquy à michemin entre Hainaut et Bassin parisien : le site de Vermand (Aisne). Bulletin de la Société préhistorique française, 100(1): 165-172. (in French) ("Some Villeneuve-SaintGermain / Blicquy in halfway between Hainaut and Paris Basin: the site of Vermand (Aisne)"), doi:10.3406/bspf.2003.12802

Bostyn, F., Arbogast, R.-M., Cayol, N., Hamon, C., Lorin, Y., Prodéo, F. 2012, Le site d'habitat Blicquy-Villeneuve-Saint-Germain de Pontpoint "le Fond de Rambourg" (Oise). Gallia Préhistoire, 54: 67-189. (in French) ("A new Blicquy/Villeneuve-SaintGermain settlement site at Pontpoint "le Fond de Rambourg" (Oise, France)")

Cahen, D., \& Van Berg, P. L. 1979, Un habitat danubien à Blicquy. I. Structures et industries lithiques. Archaeologia Belgica, 221: 39. (in French) (“A Danubian settlement at Blicquy. I. Structures and lithic industry")

Cahen, D., Caspar, J.-P., \& Otte, M. 1986, Industries lithiques danubiennes de Belgique, Etudes et Recherches Archéologiques de l'Université de Liège, 21, Liège, 88 p. (in French) ("Danubian lithic industry of Belgium")

Caspar, J.-P., Constantin C., Hauzeur A., \& Burnez-Lanotte, L. 1993, Nouveaux éléments dans le groupe de Blicquy en Belgique : le site de Vaux-et-Borset « Gibour » et « À la Croix Marie-Jeanne ». Helinium, 33(1): 67-79. (in French) ("New elements in the group of Blicquy in Belgium: the site of Vaux-et-Borset "Gibour" and "A la Croix MarieJeanne"”)

Caspar, J.-P., \& Burnez-Lanotte, L. 1994, III. Le matériel lithique. In: Nouveaux éléments dans le groupe de Blicquy en Belgique : le site de Vaux-et-Borset «Gibour » et « À la Croix Marie-Jeanne » (Caspar, J.-P., Constantin, C., Hauzeur, A., Burnez-Lanotte, L., Eds.). Helinium 34(1): 3-93. (in French) ("III. Lithic material”)

Caspar, J.-P., \& Burnez-Lanotte, L. 1996, Groupes de Blicquy-Villeneuve-Saint-Germain, nouveaux outils : le grattoir-herminette et le foret. Bulletin de la Société préhistorique française, 93(2): 235-240. (in French) ("Groups of Blicquy - Villeneuve-Saint-Germain, new tools: The scraper-adze and the bit"), doi:10.3406/bspf.1996.10145

Caspar, J.-P., \& Burnez-Lanotte, L. 1997, L'industrie lithique de Vaux-et-Borset (Hesbaye liégeoise) : nouveaux éléments dans le groupe de Blicquy (Belgique). In: Actes du 22e Colloque Interrégional sur le Néolithique, (Jeunesse, C., Ed.), Cahiers de 1'Association pour la Promotion de la Recherche Archéologique en Alsace, suppl. 3, Strasbourg: p. 411-429. (in French) ("The lithic industry of Vaux-et-Borset (Hesbaye liégeoise): New elements in the Blicquy group (Belgium)")

Caspar J.-P., Delye E., Rots V. \& Rochus N. 1999, Villers-le-Bouillet/Vaux-et-Borset : campagne de fouilles «A la Croix Marie-Jeanne ». Chronique de l'Archéologie 
wallonne, 7: 79. (in French) ("Villers-le-Bouillet/Vaux-et-Borset: campaign of excavations in "A la Croix Marie-Jeanne"”)

Caspar, J.-P., \& Burnez-Lanotte, L. 2003, Gestion des matériaux siliceux dans les premières communautés danubiennes (culture à Céramique Linéaire et groupe de Blicquy/Villeneuve-Saint-Germain) à Vaux-et-Borset (Hesbaye, Belgique). In: Production and management of lithic materials in the european Linearbandkeramik, (Burnez-Lanotte, L., Ed.), Actes du 14e Congrès UISPP, Liège, 2001, Symposium 9.3, BAR, International Series, 1200, Oxford: p. 51-58. (in French) ("Management of the siliceous materials in the first danubian communities (Linear Pottery Culture and Blicquy/Villeneuve-Saint-Germain groups) in Vaux-et-Borset (Hesbaye, Belgium)")

Caspar, J.-P., \& Burnez-Lanotte, L. 2008, Les industries lithiques des cultures du Rubané et du Blicquy-Villeneuve-Saint-Germain : mises en convergences d'analyses croisées. In: Fin des traditions danubiennes dans le Néolithique du Bassin parisien et de la Belgique (5100-4700 av. J.-C), Autour des recherches de Claude Constantin, (Burnez-Lanotte, L., Ilett, M., \& Allard, P. Eds.), mémoire 44 de la SPF, Presses Universitaires de Namur, Namur, Société préhistorique française, Paris: p. 245-268. (in French) ("The lithic industries of the Linear Pottery and Blicquy/Villeneuve-Saint-Germain cultures: put in convergences of crossed analysis")

Constantin, C. 1985, Fin du Rubané, céramique du Limbourg et Post-Rubané en Hainaut et en Bassin Parisien, British Archaeological Reports 273, Oxford: 356 p. (in French) ("End of the Linearbandkeramik, Limbourg ceramic and post-Linearbandkeramik in Hainaut and Paris Basin")

Denis, S. 2012a, Le débitage laminaire en silex tertiaire bartonien dans la culture Blicquy/Villeneuve-Saint-Germain, Néolithique ancien : organisation de la production et réseaux de circulation. Bulletin de la Société préhistorique française, 109(1): 121143. (in French) ("The laminar debitage in tertiary Bartonian flint in the Blicquy/Villeneuve-Saint-Germain Culture, Early Neolithic Period: organisation of the production and circulation network")

Denis, S. 2012b, L'industrie lithique. In: Pontavert "Route de Soissons" (Aisne) (Colas, C., Ed.), Découverte d'un village Blicquy/Villeneuve-Saint-Germain et d'une occupation du Néolithique récent/final, rapport final d'opération, diagnostique archéologique, INRAP, p. 43-52. (in French) ("The lithic industry")

Dubouloz, J. 2003, Datation absolue du premier Néolithique du Bassin parisien : complément et relecture des données RRBP et VSG. Bulletin de la Société préhistorique française, 100(4): 671-689. (in French) ("Absolute datation of the first Neolithic in Paris Basin: complement and review of the data RRBP and VSG"), doi:10.3406/bspf.2003.12903

Hubert, F. 1982, Quelques traces du Passage des Danubiens dans la région de Nivelles. Actes du Congrès de Commines, 1980, vol. 2, p. 141-148. (in French) ("Some tracks of the passage of Danubian populations in the region of Nivelles")

Jadin, I., with contributions by Cahen, D., Deramaix, I., Hauzeur, A., Heim, J., LivingstoneSmith, A., \& Verniers, J. 2003, Trois petits tours et puis s'en vont... La fin de la présence danubienne en Moyenne Belgique, Etudes et Recherches Archéologiques de l'Université de Liège Vol. 109, Liège: 726 p. (in French) ("Three small tours and then go away... The end of the danubian presence in the middle Belgium”) 
Martial, E. 2001, L'industrie lithique. In: Noyelles-sous-Lens (62) «Parcelle Bertelsman Services », (Hosdez, C., Ed.), Rapport de fouille, Service Régional de l'Archéologie Nord-Pas-de-Calais, Villeneuve d'Ascq: p. 7. (in French) ("The lithic industry")

Praud, I. (Ed.), with contributions by Bostyn, F., Hamon, C., \& Lanchon Y. 2009, Le Néolithique ancien dans la basse vallée de la Marne : un site Villeneuve-Saint-Germain producteur de lames en silex tertiaire à Ocquerre "La Rocluche »(Seine-et-Marne), Société préhistorique Française, Travaux 9, Paris: 141 p. (in French) ("The Early Neolithic in the low valley of the Marne: a Villeneuve-Saint-Germain producer site of blades in tertiary flint in Ocquerre "La Rocluche" (Seine-et-Marne)")

Praud, I., Bostyn, F., Cayol, N., Hamon, C., Ladureau, P., Lanchon, Y., Pinard, E. 2010, Entre Blicquy et Villeneuve-Saint-Germain, présentation de la fouille d'un habitat du Néolithique ancien à Loison-sous-Lens (Pas-de-Calais). In: Premiers Néolithiques de l'Ouest: Cultures, réseaux, échanges des premières sociétés néolithiques à leur expansion, 28e colloque interrégional sur le Néolithique, (Billard, C., \& Legris, M., Eds.), Presses Universitaires de Rennes, Rennes: p. 305-323. (in French) ("Between Blicquy and Villeneuve-Saint-Germain, presentation of the excavation of an Early Neolithic settlement at Loison-sous-Lens (Pas-de-Calais)")

Robaszynski, F., V. Dhondt, A. \& WM. Jagt, J. 2001, Cretaceous lithostratigraphic units (Belgium). Geologica Belgica, 4(1-2): 121-134. 